УДК 331.101 .26

\title{
ЗАВДАННЯ ЕКОЛОГІЧНОГО МЕНЕДЖМЕНТУ ЧЕРЕЗ ПРИЗМУ РОЗВИТКУ КОНЦЕПЦї КОРПОРАТИВНОЇ ВІДПОВІДАЛЬНОСТІ
}

\section{TASKS OF ENVIRONMENTAL MANAGEMENT THROUGH THE PRISM OF DEVELOPING THE CONCEPT OF CORPORATE RESPONSIBILITY}

\author{
Касич Алла Олександрівна \\ доктор економічних наук, профресор, \\ Київський національний університет технологій та дизайну \\ ORCID: https://orcid.org/0000-0001-7019-1541 \\ Паламарчук Валентина Андріївна \\ аспірантка, \\ Київський національний університет технологій та дизайну \\ ORCID: https://orcid.org/0000-0001-9465-0669 \\ Kasych Alla, Palamarchuk Valentyna \\ Kyiv National University of Technology and Design
}

\begin{abstract}
Розглянуто різні ідеї щодо визначення поняття «екологічна відповідальність». Проаналізовано видовий комплекс екологічної відповідальності. Виявлено необхідність забезпечення належного рівня екологічної відповідальності з метою отримання конкурентних переваг як на внутрішньому, так і на міжнародному ринку серед передових компаній. Наведено ознаки екологічно відповідального підприємства, яке має сприяти реалізації екологічних програм та надавати у відкритому вигляді інформацію про діяльність організації, що впливає на суспільство, економіку та довкілля в цілому. З'ясовано особливості екологічної відповідальності підприємства.

Ключові слова: екологічна відповідальність, корпоративна екологічна відповідальність, екологічна відповідальність підприємства, екологічно орієнтоване підприємство, екологічна свідомість.
\end{abstract}

Рассмотрены различные идеи относительно определения понятия «экологическая ответственность». Проанализирован видовой комплекс экологической ответственности. Отмечена необходимость обеспечения надлежащего уровня экологической ответственности с целью получения конкурентных преимуществ как на внутреннем, так и на международном рынке среди передовых компаний. Наведено признаки экологически ответственного предприятия, которое должно способствовать реализации экологических программ и предоставлять в открытом виде информацию о деятельности организации, которая влияет на общество, экономику и окружающую среду в целом. Выяснены особенности экологической ответственности предприятия.

Ключевые слова: экологическая ответственность, корпоративная экологическая ответственность, экологическая ответственность предприятия, экологически ориентированное предприятие, экологическое сознание.

The article is devoted to topical issues of definition, specification and understanding of the tasks facing the environmental management system at the enterprise. Since the factor of environmental responsibility has historically been given the least attention in the process of managing the development of Ukrainian enterprises, there is an objective need to meaningfully review the interaction of modern production processes and the environment, as well as justify new approaches to environmental responsibility. To solve certain problems, the method of theoretical generalization, analysis and synthesis was used - to clarify the nature and main components of environmental responsibility of the enterprise; analytical - substantiation, refutation of various scientific positions; abstract - logical - the formation of conclusions and generalizations. During the study, various ideas and approaches to the definition of "environmental responsibility" were considered. The species complex of ecological responsibility is analyzed. The meaning of the concept from the philosophical point of view is determined, taking into account both the legal form of manifestation and the economic one. The signs and characteristics of an environmentally responsible enterprise, which should promote the implementation of environmental programs and provide open information about the activities of the organization, which affects society, economy and the environment as a whole, namely: activities that 
benefit the environment or reduce negative business impact on the environment, focus not only on profit, but also on the preservation of the natural environment and compensation for losses from its industrial activities, the existence of an effective management system that acts in the interests of the enterprise, ensuring thus addressing issues related to the protection and improvement of the environment. The peculiarities of the ecological responsibility of the enterprise are found out. The study showed the need to ensure an appropriate level of environmental responsibility in order to gain a competitive advantage in both domestic and international markets among leading companies. The practical value of the article is to address the issues of efficient use of nature in enterprises in modern conditions. The basis of such management should be a clear understanding of the content and key characteristics of the concept of corporate responsibility with an emphasis on environmental issues.

Keywords: ecological responsibility, corporate ecological responsibility, ecological responsibility of the enterprise, ecologically oriented enterprise, ecological consciousness.

Постановка проблеми. Сучасний економічний розвиток відбувається в умовах глобальної екологічної кризи, що обумовлена дією антропогенних і техногенних чинників. Вплив підприємницької діяльності на довкілля досягнув критичної точки. Наслідком бездумної діяльності може стати катастрофра світового масштабу. Саме це і визначає об'єктивну необхідність змістовного переосмислення взаємодії сучасних процесів виробництва та навколишнього природного середовища, a також обґрунтування нових підходів до визначення екологічної відповідальності, оскільки цьому фрактору історично приділялося найменше уваги в процесі управління розвитком на українських підприємствах.

Аналіз останніх досліджень і публікацій. Основні положення концепції екологічної відповідальності висвітлили в своїх працях як зарубіжні, так і українські науковці. Маршал А. С. та Браун Д. [26] розглядали екологічну відповідальність як комплекс не лише компенсаційних заходів від нанесеної шкоди довкіллю, але і попереджувальних. Мілль Д. [11], досліджуючи взаємодію підприємництва та довкілля, трактував природні ресурси як «багатство». Огородник В. В. [14] та Охріменко О. О. [15], розглядали екологічну відповідальність, як складову частину соціальної та загалом корпоративної відповідальності.

Крім того, багато дослідників розглядали екологічну відповідальність, як один із засобів екологізації діяльності промислових підприємств. 3 етичної точки зору, як комплекс добровільних заходів, що виходять за рамки законодавства у сорері довкілля, екологічну відповідальність розглядали Гаєвська М. В. [2], Хаянок Т. М. [18], Колісник 3. Б [4]. Купалова Г. І. [6] та Шаповал В. М. [28] розглядали екологічну відповідальність бізнесу як невід'ємний компонент сталого розвитку підприємства. Крім того, Шаповал В. М., Коваленко О. А. [19] вбачали під екологічною відповідальністю раціональне природокорис- тування. Питання даної проблематики також було розглянуто в працях [24; 25].

Екологічну відповідальність як один із засобів екологізації діяльності промислових підприємств, розглядали Кукутич Є. Ю. [5], Боровик О. Н. [1], Шапіра Ф. та Гок. А. [27, с. 93], Погорелов Ю. С. [13, с. 51], Петрушенко М. М. [11], Мельник Л. Г. [8]. У вище наведених працях представлено ознаки й особливості, критерії характеристики екологічно відповідального підприємства.

Аналіз досліджень та публікацій показує, що зростання й розвиток бізнесу повинні бути як економічно, так і екологічно сталими. Турбота про навколишнє середовище й скорочення масштабів впливу виробництва на екологію $€$ важливими аспектами діяльності підприємства та основою екологічно орієнтованого менеджменту.

Виділення невирішених раніше частин загальної проблеми. Подальшого вивчення потребують питання забезпечення ефрективного екологічного менеджменту на підприємствах в умовах сьогодення, основою якого має стати чітке розуміння змісту та ключових характеристик концепції корпоративної відповідальності з акцентом на питаннях природокористування.

Мета статті полягає у конкретизації та осмисленні завдань, що постають перед системою екологічного управління на підприємстві, виходячи із узагальнення підходів щодо обґрунтування змісту концепції екологічної відповідальності.

Виклад основного матеріалу дослідження. Екологічні проблеми в їх сучасному виявленні $\epsilon$ предметом пильної уваги фрахівців протягом більш ніж п'ятдесяти років. Промислові підприємства несуть вагому частку відповідальності за їх загострення і поступово активізують зусилля в напрямку екологізації своєї діяльності.

Питання подальшого економічного розвитку завжди поставало в науці, насамперед 
через обмеженість природних ресурсів, а особливо через їх використання у сорері обміну та розподілу між людьми. Використання природних ресурсів, що мають обмежений характер, розглядалися науковцями в контексті аналізу економічного зростання. Ще наприкінці XVII століття Рікардо Д. [20] висунув ідею щодо обмеженості сільськогосподарських земель і закону спадної віддачі як чинників, що лімітують виробництво продовольчого та економічного розвитку в цілому. До цього часу безпрецедентний антропогенний пресинг на довкілля аж ніяк не зменшився, незважаючи на численні спроби людства зробити його більш зваженим і толерантним. Окрім слідування стандартам в сорері захисту довкілля, заохочується ініціативна поведінка у формуванні нової, відповідальної етики підприємницької діяльності.

У 70-х роках XX століття становлення корпоративної соціальної відповідальності пов'язується 3 екологічною відповідальністю, яка почала фрормуватися у відповідь на масштабні екологічні проблеми, спричинені діяльністю великих компаній. Green Paper Європейського союзу визначає корпоративну соціальну відповідальність як «Концепцію, в рамках якої компанії на добровільній основі інтегрують соціальну і екологічну політику в бізнес-операції і їх взаємини з усим колом пов'язаних 3 компанією організацій і людей» [23]. У той же час починається суспільний рух щодо охорони довкілля, захисту прав працівників та споживачів. Основою екологічної відповідальності бізнесу $€$ концептуальні положення корпоративної соціальної відповідальності.

Намагаючись дослідити коріння корпоративної екологічної відповідальності, варто розглянути концепцію соціальної відповідальності бізнесу, що запропонував Керролл А. [22]. Згідно моделі Керролла А., корпоративна соціальна відповідальність являє собою багаторівневу відповідальність, яку можна представити у вигляді піраміди. В основі піраміди Керролла А. лежить економічна відповідальність, другий рівень - правова відповідальність, третій рівень - етична і четвертий рівень - фрілантропічна (дискреційна) відповідальність. Екологічний аспект корпоративної соціальної відповідальності наявний у блоці економічної відповідальності, у правовій відповідальності, у блоці етичної відповідальності, крім того, можна виокремити аспект сталого розвитку в орілантропічному блоці, адже сталий розвиток включає три основні складові: економічну, екологічну та соціальну, при чому всі вони знаходяться у тісному взаємозв'язку та взаємозалежності. Тобто, кожен з перерахованих рівнів висвітлює основну ідею корпоративної екологічної відповідальності - люди повинні глибше усвідомлювали вплив на навколишнє середовище та протидіяли забрудненню. А також й основну ціль, яка полягає у знаходженні точки рівноваги між економічним зростанням, зменшенням відходів і чистішим середовищем.

Мазуркевич П. [8] розглядає корпоративну екологічну відповідальність та трактує їі як обов'язок компанії утримуватися від шкідливого природного середовища. Саме тому, корпоративну екологічну відповідальність слід розглядати як добровільне намагання корпорацій виміряти та мінімізувати екологічні наслідки своєї підприємницької діяльності.

Екологічна відповідальність згідно 3 Директивою 2004/35/€С [3] передбачає зобов'язання забруднювача вжити заходи із запобігання настанню екологічної шкоди чи ліквідації наслідків екологічної шкоди для відновлення природних ресурсів до стану, що існував до її заподіяння, та покриття ним витрат на проведені заходи.

Огородник В.В.під концепцією екологічної відповідальності розуміє «діяльність як кожного окремого громадянина, так і бізнес-структур, яка приносить користь навколишньому природному середовищу (або зменшує негативний вплив на навколишнє середовище). Крім того, дана діяльність не обмежується тільки визначеними законом та обов'язковими до виконання заходами» $[14$, с. 612].

Шаповал В. М., Коваленко О. А. трактують екологічну відповідальність як «свідому добровільну участь бізнесу у різноманітних заходах, направлених на попередження та мінімізацію негативного впливу на навколишнє середовище; раціональне природокористування; економію сировинних та енергетичних ресурсів у процесі господарської діяльності; залучення відходів у господарський обіг; запобігання аварійних і надзвичайних ситуацій; підтримку заходів з охорони здоров'я; збереження культурно-історичної спадщини, біорізноманіття та природних територій, які потребують особливої охорони; збереження зникаючих біологічних видів тощо» [19, с. 159].

Більш ширшим поняттям $€$ «екологічна відповідальність підприємства», що з'являється у роботах зарубіжних вчених починаючи 3 2000-х років. Дослідники розглядають екологічну відповідальність як один із засобів екологізації діяльності промислових підпри- 
ємств, а також як певну сукупність процесів та цілеспрямованих дій, що направлені на мінімізацію антропогенних викидів і максимізацію екологічно орієнтованої промислової діяльності, і до того ж цей комплекс повинен задовольняти умови стейкхолдерів. Комплекс науково-обґрунтованих ідей, що дає змогу виокремити певні особливості екологічного підприємства, представлено в таблиці 1.

Узагальнюючи вищенаведене науковцями, можна сказати, що екологічна відповідальність підприємства базується на добровільних

Науково-обґрунтовані ідеї екологічної відповідальності підприємства

Таблиця 1

\begin{tabular}{|c|c|c|}
\hline Представник & $\begin{array}{c}\text { Наукове обґрунтування } \\
\text { екологічної відповідальності } \\
\text { підприємства }\end{array}$ & Базисна характеристика \\
\hline $\begin{array}{c}\text { Гаєвська М. } \\
\text { [2] }\end{array}$ & $\begin{array}{l}\text { Розробка і реалізація комплексу } \\
\text { заходів, що виходять за рамки } \\
\text { законодавства в ссрері охорони } \\
\text { довкілля. }\end{array}$ & $\begin{array}{l}\text { Екологічно орієнтовані } \\
\text { підприємства повинні провадити } \\
\text { еко-зберігаючу політику, а також } \\
\text { діяльність з раціональним } \\
\text { використанням, збереженням, } \\
\text { відновленням та охороною } \\
\text { природних ресурсів, екологічною } \\
\text { безпекою. }\end{array}$ \\
\hline $\begin{array}{c}\text { Хаянок Т. } \\
\text { [18] }\end{array}$ & $\begin{array}{l}\text { Етичне виправдання економічної } \\
\text { свободи промислового } \\
\text { підприємства. }\end{array}$ & $\begin{array}{l}\text { Інтереси підприємства не повинні } \\
\text { протирічити інтересам стейкхолдерів, } \\
\text { зокрема інтересам екології. Тобто, } \\
\text { на шляху до отримання прибитку, } \\
\text { екологічно орієнтоване підприємство } \\
\text { на перший план ставить збереження } \\
\text { довкілля та задоволення потреб } \\
\text { соціуму. } \\
\text { Цільова установка екологічно } \\
\text { орієнтованого підприємства полягає у } \\
\text { гармонізації взаємовідносин людини і } \\
\text { природи, тобто охороні довкілля. }\end{array}$ \\
\hline $\begin{array}{c}\text { Магомедов Т. } \\
\text { [7] }\end{array}$ & $\begin{array}{l}\text { Ведення господарської діяльності } \\
\text { промислових підприємств, при } \\
\text { якому забезпечується дотримання } \\
\text { вимог природоохоронного } \\
\text { законодавства, а локальній } \\
\text { екосистемі наноситься збиток } \\
\text { в розмірі, що не перевищує } \\
\text { асиміляційний потенціал території. }\end{array}$ & $\begin{array}{l}\text { Діяльність екологічно орієнтованих } \\
\text { підприємств повинна базуватися на } \\
\text { гуманному природокористуванні. }\end{array}$ \\
\hline $\begin{array}{l}\text { Маршалл A., } \\
\text { Браун Д. } \\
\text { (Marshall A. S., } \\
\text { Brown D.) [26] }\end{array}$ & $\begin{array}{l}\text { Не лише компенсація шкоди, } \\
\text { що спричинена діяльністю } \\
\text { промислового підприємства, а і } \\
\text { проведення попереджувальних цей } \\
\text { збиток заходів. }\end{array}$ & $\begin{array}{l}\text { Екологічно орієнтоване } \\
\text { підприємство повинно проводити } \\
\text { комплекс природоохоронних дій. }\end{array}$ \\
\hline $\begin{array}{c}\text { Салдаєва М. } \\
\text { [17] }\end{array}$ & $\begin{array}{l}\text { Являє собою комплекс з юридичної } \\
\text { (регулюється адміністративно- } \\
\text { правовими методами, нормами } \\
\text { екологічного законодавства) } \\
\text { і економічної (базується на } \\
\text { правомірній діяльності із позитивним } \\
\text { характером відповідальності, } \\
\text { регулюється за рахунок економічних } \\
\text { методів) складових. }\end{array}$ & $\begin{array}{l}\text { Економічна діяльність екологічно } \\
\text { орієнтованого підприємства не } \\
\text { повинна суперечити законодавству } \\
\text { у сорері охорони довкілля. Тобто, } \\
\text { діяльність не лише в рамках } \\
\text { діючого законодавства, але й } \\
\text { екологічного. }\end{array}$ \\
\hline $\begin{array}{c}\text { Колісник } 3 . \\
{[4]}\end{array}$ & $\begin{array}{l}\text { Добровільні зобов'язання } \\
\text { промислового підприємства } \\
\text { щодо виконання соціальних та } \\
\text { екологічних програм, пов'язаних зі } \\
\text { стратегією розвитку підприємства } \\
\text { і не суперечить ефективному } \\
\text { управлінню. }\end{array}$ & $\begin{array}{l}\text { Екологічна діяльність екологічно } \\
\text { орієнтованого підприємства не } \\
\text { повинна суперечити інтересам } \\
\text { самого підприємства та його } \\
\text { стратегії розвитку. }\end{array}$ \\
\hline
\end{tabular}


(Закінчення таблиці 1)

\begin{tabular}{|c|c|c|}
\hline Представник & $\begin{array}{c}\text { Наукове обґрунтування } \\
\text { екологічної відповідальності } \\
\text { підприємства } \\
\end{array}$ & Базисна характеристика \\
\hline 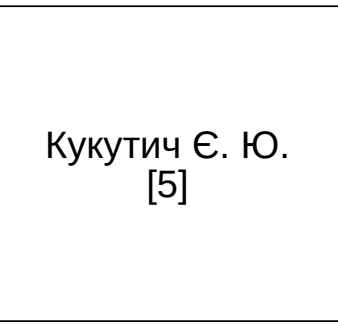 & $\begin{array}{l}\text { Форма підприємницької діяльності, } \\
\text { що базується на задоволенні } \\
\text { екологічно економічних потреб } \\
\text { за рахунок продуктів з визначною } \\
\text { екологічною корисністю, а компоненти } \\
\text { екологічної системи розглядаються } \\
\text { як фрактори, що визначають еколого- } \\
\text { економічні потреби. }\end{array}$ & $\begin{array}{l}\text { Економічна діяльність екологічно } \\
\text { орієнтованого підприємства } \\
\text { направлена на задоволення } \\
\text { екологічних потреб. }\end{array}$ \\
\hline $\begin{array}{c}\text { Боровик О. Н. } \\
\text { [1] }\end{array}$ & $\begin{array}{l}\text { Процес забезпечення якості } \\
\text { навколишнього середовища } \\
\text { та ощадливого використання } \\
\text { природних ресурсів, яка є } \\
\text { прийнятною для суспільства } \\
\text { та відповідною до нормативно- } \\
\text { правових вимог. }\end{array}$ & $\begin{array}{l}\text { Діяльність екологічно орієнтованого } \\
\text { підприємства направлена на } \\
\text { створення та реалізацію економічного } \\
\text { механізму збалансування інтересів } \\
\text { із суспільством у просторі екологічно } \\
\text { економічних відносин та розв'язання } \\
\text { екологічно економічних протиріч. }\end{array}$ \\
\hline $\begin{array}{c}\text { Шапіра Ф. } \\
\text { та Гок. A. } \\
\text { (Shapira Ph., } \\
\text { Gök A.) } \\
{[27, \text { c. 93] }}\end{array}$ & $\begin{array}{l}\text { Діяльність і розвиток, що } \\
\text { відбуваються не за рахунок } \\
\text { природних систем і не призводять } \\
\text { до зниження здоров'я населення. }\end{array}$ & $\begin{array}{l}\text { Діяльність екологічно орієнтованого } \\
\text { підприємства направлена на } \\
\text { екологізацію виробництва: мінімальне } \\
\text { використання електроенергії } \\
\text { (оптимальним рішенням можуть стати } \\
\text { сонячні батареї), використання еко- } \\
\text { тари, вторинна переробка сировини, } \\
\text { відходів і так далі. Тобто, головною } \\
\text { метою є безвідходність виробничих } \\
\text { процесів. }\end{array}$ \\
\hline $\begin{array}{c}\text { Погорєлов Ю. С. } \\
{[13, \text { с.51] }}\end{array}$ & $\begin{array}{l}\text { Процес впровадження технологічних, } \\
\text { управлінсько-правових методів, які } \\
\text { передбачають забезпечення випуску } \\
\text { необхідної продукції у потрібній кіль- } \\
\text { кості та достатньої якості, але за пев- } \\
\text { них умов: підвищення ефективності } \\
\text { використання природних ресурсів та } \\
\text { зменшення антропогенного наванта- } \\
\text { ження на навколишнє середовище. }\end{array}$ & $\begin{array}{l}\text { Процес ефективної економічної } \\
\text { діяльності екологічно орієнтовано } \\
\text { підприємства має поєднуватися } \\
\text { з «розумним» використанням } \\
\text { природних ресурсів. }\end{array}$ \\
\hline $\begin{array}{c}\text { Петрушенко М. М. } \\
{[11, \text { с.74] }}\end{array}$ & $\begin{array}{l}\text { Комплекс заходів для досягнення } \\
\text { оптимального балансу між } \\
\text { екологічними та економічними } \\
\text { цілями фрункціонування } \\
\text { підприємства. }\end{array}$ & $\begin{array}{l}\text { Діяльність екологічно орієнтованого } \\
\text { підприємства спрямована на } \\
\text { економічну вигоду без пресингу } \\
\text { на довкілля та забезпечення } \\
\text { системи ефективного екологічного } \\
\text { менеджменту, враховуючи специфріку } \\
\text { та потреби екологічного виробництва. }\end{array}$ \\
\hline $\begin{array}{c}\text { Мельник Л. Г. } \\
\text { [9] }\end{array}$ & $\begin{array}{l}\text { Вид підприємницької діяльності, } \\
\text { який пов'язаний з випуском і } \\
\text { реалізацією екологічної продукції } \\
\text { (виробів, послуг, робіт). }\end{array}$ & $\begin{array}{l}\text { Екологічно орієнтоване підприємство } \\
\text { фокусується на «зеленій» діяльності. } \\
\text { Основна діяльність з виробництва } \\
\text { продукції, виконання робіт та } \\
\text { надання послуг спеціального } \\
\text { природоохоронного призначення. }\end{array}$ \\
\hline $\begin{array}{c}\text { Купалова Г. І. } \\
\text { [6] }\end{array}$ & $\begin{array}{l}\text { Виробництво товарів та } \\
\text { надання послуг з вимірювання, } \\
\text { попередження, обмеження або } \\
\text { усунення екологічної шкоди, } \\
\text { ліквідації відходів та зниження } \\
\text { рівня шуму, а також екологічно } \\
\text { чисті технології, застосування яких } \\
\text { мінімізує використання сировини та } \\
\text { забруднення довкілля. }\end{array}$ & $\begin{array}{l}\text { Основний напрям розвитку } \\
\text { екологічно орієнтованого } \\
\text { підприємства ґрунтується на } \\
\text { екологічній якості продукції, робіт, } \\
\text { послуг. }\end{array}$ \\
\hline
\end{tabular}

Джерело: систематизовано авторами на основі [1; 2; 4-7; 9; 11, с. 74; 13, с. 51; 17-18; 26; 27, с. 93] 
етичних засадах стосовно гуманного використання природних ресурсів. Вона перестає бути чимось примусовим, перетворюючись у внутрішні правила ведення бізнесу.

Доцільним буде зазначити, що від моменту появи в науковій літературі до сьогодення, відповідні теоретичні ідеї щодо місця і ролі екологічної відповідальності у виробничій діяльності підприємств зазнали помітних змін. Для отримання цілісної картини розуміння даного поняття, необхідно розглянути різні підходи, оскільки екологічна відповідальність по-різному інтерпретується представниками економічних напрямів (див. табл. 2).

Крім того, в працях [12; 16; 21] науковцями представлено видову класифікацію екологічної відповідальності, яку наведено в таблиці 3.

Сучасне бачення концепції екологічної відповідальності (рис. 1) орієнтоване не стільки на продукування, як на власне екологічне виробництво. Саме тому екологічно відпові- дальні компанії вдаються до концепції екологічного менеджменту.

Тобто, екологічно відповідальна діяльність підприємства передбачає якісне «зелене» виробництво, гуманне безвідходне використання природних ресурсів, ефрективну екологічно свідому систему менеджменту, збереження навколишнього середовища для нинішнього суспільства та наступних поколінь.

На сьогоднішній день, корпоративна екологічна відповідальність є актуальною як для великих корпорацій, так і для малих підприємств. Така відповідальність є більш інституціоналізованою, що полягає в усвідомленні зацікавленими сторонами величезного впливу ділової діяльності на навколишнє середовище. Саме тому виникає важливість розробки нових стратегій, основою яких є екологічна відповідальність, та які допомагатимуть у створенні ефрективного та екологічностійкого бізнесу.

Таблиця 2

Основоположні ідеї та підходи до визначення поняття «екологічна відповідальність»

\begin{tabular}{|c|c|}
\hline Підхід & Трактування/визначні риси \\
\hline Класичний & $\begin{array}{l}\text { Екологічна відповідальність виникла під дією екологічного } \\
\text { законодавства: щоб уникнути санкцій, підприємства змушенні були } \\
\text { переглянути свою екологічну політику і вжити заходів для зменшення } \\
\text { негативного впливу своєї діяльності на навколишнє середовище. }\end{array}$ \\
\hline Неокласичний & $\begin{array}{l}\text { Екологічна відповідальність є наслідком не лише нормативно-правових } \\
\text { обмежень, а й моральної відповідальності виробників за заподіяння } \\
\text { шкоди природі. }\end{array}$ \\
\hline $\begin{array}{l}\text { Інтегрований } \\
\text { економіко- } \\
\text { етичний }\end{array}$ & $\begin{array}{l}\text { Передбачає врахування етичних факторів (стосується також і } \\
\text { навколишнього середовища) при прийнятті управлінських рішень. } \\
\text { Базується на наступних основних принципах: } \\
\text { - поліпшення матеріального й нематеріального добробуту; } \\
\text { - забезпечення справедливості у стосунках різних поколінь людей, що } \\
\text { ставить завдання урахування впливу поведінки нинішніх поколінь на } \\
\text { можливості задоволення потреб поколінь майбутніх; } \\
\text { - забезпечення справедливості у відносинах між людьми з урахуванням } \\
\text { того, що відсутність рівного доступу до товарів і ресурсів є одним з } \\
\text { найважливіших джерел соціального занепаду й екологічної деградації; } \\
\text { - захист біорізноманітності й підтримка екологічних систем; - визнання } \\
\text { важливості урахування глобальних наслідків здійснюваних бізнес-дій, як } \\
\text { і зворотного впливу екологічної політики на торгівлю й економіку. }\end{array}$ \\
\hline $\begin{array}{l}\text { Неоінституційно- } \\
\text { етичний }\end{array}$ & $\begin{array}{l}\text { Екологічна відповідальність полягає в наявності зобов'язань етичного та } \\
\text { екологічного характеру організації перед певними групами зацікавлених } \\
\text { осіб - стейкхолдерами. }\end{array}$ \\
\hline $\begin{array}{l}\text { Соціально- } \\
\text { етичний }\end{array}$ & $\begin{array}{l}\text { Екологічна відповідальність - частина корпоративної соціальної } \\
\text { відповідальності. Менеджери і співробітники відповідають за } \\
\text { збалансоване слідування компанією спільним інтересам. }\end{array}$ \\
\hline $\begin{array}{l}\text { Радикально- } \\
\text { екологічний }\end{array}$ & $\begin{array}{l}\text { Має різні формми прояву: екофемінізм, соціальна екологія, захист прав } \\
\text { тварин, теорія екологічних співтовариств тощо. }\end{array}$ \\
\hline Сталий розвиток & $\begin{array}{l}\text { Стратегічна мета - збереження балансу соціо-еколого-економічної } \\
\text { системи. Врахування екологічних фракторів при прийнятті управлінських } \\
\text { рішень. Екологічна відповідальність знімає конфлікт інтересів } \\
\text { стейкхолдерів, сприяє сталому розвитку суспільства. }\end{array}$ \\
\hline
\end{tabular}


Видова класифрікація екологічної відповідальності

Таблиця 3

\begin{tabular}{|c|c|}
\hline Вид & Визначення \\
\hline $\begin{array}{l}\text { Еколого-правова } \\
\text { відповідальність }\end{array}$ & $\begin{array}{l}\text { Передбачає відповідальність за скоєння екологічних } \\
\text { правопорушень, що є важливим складовим елементом } \\
\text { правового забезпечення раціонального природокористування } \\
\text { та відновлення екологічних об'єктів і охорони довкілля. }\end{array}$ \\
\hline $\begin{array}{c}\text { Екологічна відповідальність } \\
\text { бізнесу }\end{array}$ & $\begin{array}{l}\text { Дії, які приносять користь навколишньому середовищу або } \\
\text { зменшують негативний вплив на нього, і виходять за рамки } \\
\text { того, що компанії зобов'язані робити за законом. Включає } \\
\text { зобов'язання осіб, що приймають рішення, запроваджувати } \\
\text { дії, спрямовані на захист і поліпшення стану довкілля, які } \\
\text { також не перешкоджають їх власним бізнес-інтересам. }\end{array}$ \\
\hline $\begin{array}{l}\text { Екологічна відповідальність } \\
\text { як частина корпоративної } \\
\text { соціальної відповідальності }\end{array}$ & $\begin{array}{l}\text { Передбачає усвідомлену та умотивовану участь бізнесу } \\
\text { у різноманітних заходах, спрямованих на попередження } \\
\text { та мінімізацію негативних впливів на довкілля, економію } \\
\text { сировинних і енергетичних ресурсів, раціональне } \\
\text { природокористування, використання відходів, попередження } \\
\text { аварійних та надзвичайних ситуацій, підтримка заходів } 3 \\
\text { охорони здоров'я тощо. }\end{array}$ \\
\hline $\begin{array}{l}\text { Екологічна відповідальність } \\
\quad \text { як стратегія стійкого } \\
\text { розвитку }\end{array}$ & $\begin{array}{l}\text { Мається на увазі стратегія, згідно з якою керівництво компанії } \\
\text { вирішує слідувати бажаній екологічній ефективності, а саме } \\
\text { до виконання принципів стійкого розвитку. }\end{array}$ \\
\hline $\begin{array}{c}\text { Екологічна відповідальність } \\
\text { з позицій екоменеджменту }\end{array}$ & $\begin{array}{l}\text { Передбачає поєднання певних дій, функцій та повноважень, } \\
\text { які необхідні для здійснення управлінського еколого- } \\
\text { соціального впливу. Характеризується взаємодією органів } \\
\text { владних повноважень і безпосередньо підприємницьких } \\
\text { структур в сфері нагляду, контролю, аудиту, оцінювання } \\
\text { впливу на навколишнє середовище. }\end{array}$ \\
\hline
\end{tabular}

Джерело: розробка авторів на основі [12; 16; 21]

Систематизація та аналіз різних підходів, дали змогу сорормувати нове бачення екологічної відповідальності, як системи заходів, що направлена на екологічно модернізовану діяльність та, яка базується на нормативно-правових і морально-етичних принципах стосовно навколишнього природного середовища.

Отже, екологічна відповідальність $€$ необхідною умовою виживання і процвітання компанії. Імплементація даної концепції має стати стратегічним рішенням для українських підприємств, що вплине на їх внутрішній розвиток, відносини між стейкхолдерами, організаціями і владою. Саме тому підприємствам варто зосередитися на всіх аспектах сталого розвитку - економічному, екологічному і соціальному, мінімізувавши екологічне навантаження від розвитку та зростання самого підприємства.

Висновок. Проведене нами дослідження показало, що науковці розглядали екологічне управління в контексті розвитку загальної концепції корпоративної відповідальності. Це пов'язано 3 тими обставинами, що основна позиція екологічно орієнтованого підприємства полягає в гармонійному співіснуванні зі стейкхолдерами, постійному діалозі з суспільством, участі у вирішенні гострих екологічних питань.

Систематизація наукових підходів дозволила визначити такі характеристики екологічно відповідального підприємства:

- дії, які приносять користь навколишньому середовищу або зменшують негативний вплив бізнесу на навколишнє середовище, виходячи за рамки того, що компанії зобов'язані робити за законом;

- екологічно відповідальні підприємства зорієнтовані не лише на отримання прибутку, а й на збереження природного середовища та на компенсацію збитків від своєї промислової діяльності.

- екологічна відповідальність бізнесу передбачає ефрективно діючу систему менеджменту, яка повинна забезпечувати вирішення питань щодо захисту і поліпшення стану навколишнього середовища в цілому, не порушуючи при цьому інтереси компанії. 


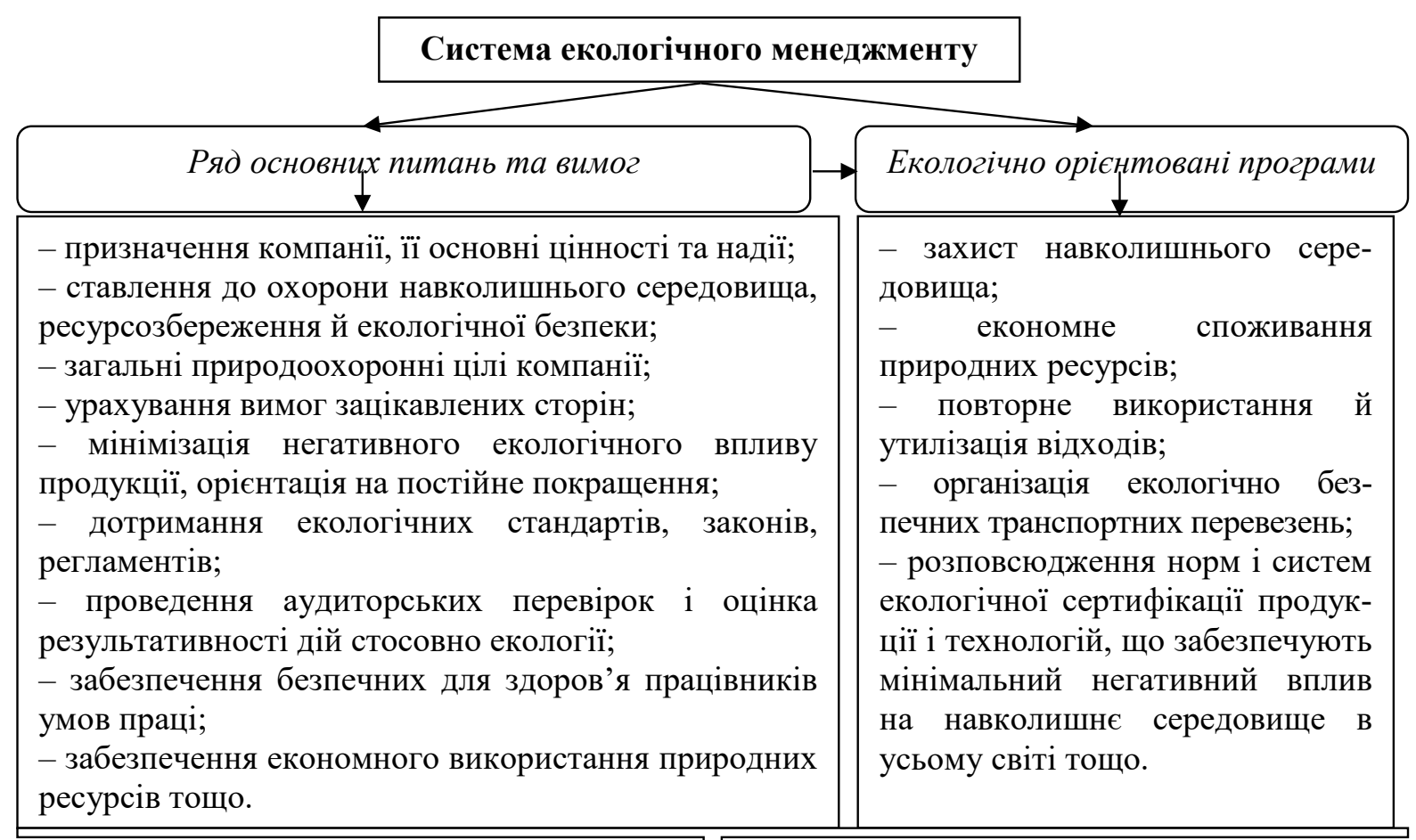

\begin{tabular}{|c|c|c|c|}
\hline \multicolumn{4}{|c|}{25} \\
\hline $\begin{array}{c}\text { Дотримання екологічних } \\
\text { зобов 'язань }\end{array}$ & \multicolumn{2}{|c|}{$\begin{array}{c}\text { Енергетичний та } \\
\text { сировинний менеджмент }\end{array}$} & \\
\hline $\begin{array}{l}\text { - відповідність корпоративного } \\
\text { бачення концепції сталого } \\
\text { розвитку; } \\
\text { - стратегічна пріоритетність } \\
\text { захисту та відновленню } \\
\text { природного середовища; } \\
\text { - усвідомлення обмеженості } \\
\text { екосистеми, в рамках якої } \\
\text { функціонує підприємство; } \\
\text { - відповідність діяльності вимо- } \\
\text { гам екологічного законодавства; } \\
\text { - відповідальність за шкоду, } \\
\text { завдану довкіллю; } \\
\text { - екологічні цінності в культурі } \\
\text { компаніі. }\end{array}$ & $\begin{array}{l}- \text { ефек } \\
\text { природ } \\
- \\
\text { викори } \\
\text { відновл } \\
\text { матеріа } \\
\text { - систе } \\
-\quad \text { мі } \\
\text { вуглекц } \\
-\quad \text { ан } \\
\text { досягнє } \\
\text { екологі } \\
\text { - аналі } \\
\text { та пере }\end{array}$ & $\begin{array}{l}\text { гивне використання } \\
\text { них ресурсів; } \\
\text { створення } \\
\text { тання } \\
\text { юваної енергії та } \\
\text { пів; } \\
\text { ине мислення; } \\
\text { німізація викидів } \\
\text { слого газу; } \\
\text { аліз екологічних } \\
\text { нь та пошук нових } \\
\text { нних рішень; } \\
\text { екологічних витрат } \\
\text { заг. }\end{array}$ & 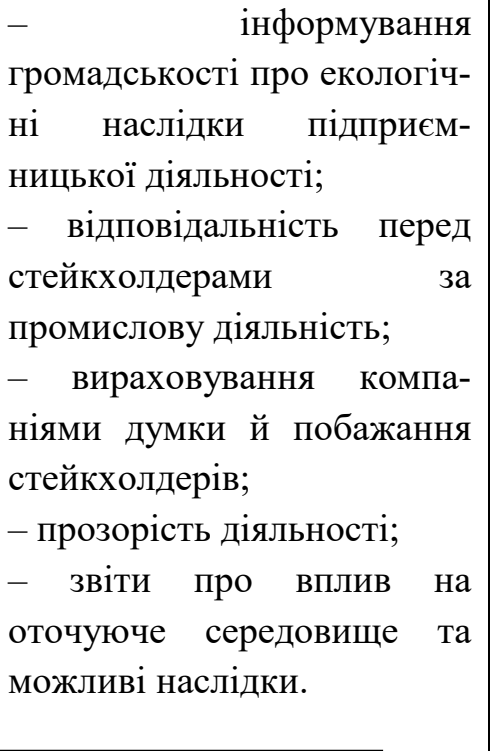 \\
\hline \multicolumn{4}{|c|}{ Переваги від запровадження екологічної відповідальності бізнесу } \\
\hline & & \\
\hline \multicolumn{2}{|l|}{ Держава та суспільство } & \multicolumn{2}{|c|}{ Екологічно орієнтоване підприємство } \\
\hline \multicolumn{2}{|c|}{$\begin{array}{l}-\quad \text { вирішення частини ключових } \\
\text { екологічних питань; } \\
-\quad \text { відповідність нормам і стандартам } \\
\text { світової економіки з урахуванням } \\
\text { екологічної складової; } \\
-\quad \text { збереження здоров’я населення тощо. }\end{array}$} & \multicolumn{2}{|c|}{$\begin{array}{l}\text { - поліпшення результатів діяльності як у } \\
\text { короткостроковій, так і у довгостроковій } \\
\text { перспективі; } \\
\text { - забезпечує відповідний імідж на міжнародній } \\
\text { арені або на вітчизняному ринку та прихильність } \\
\text { споживачів, популярність тощо. }\end{array}$} \\
\hline
\end{tabular}

Рис. 1. Система менеджменту екологічно орієнтованого підприємства 


\section{СПИСОК ВИКОРИСТАНИХ ДЖЕРЕЛ:}

1. Боровик О.Н. Екологічне підприємництво та його переваги. Управління інноваційним процесом в Україні: проблеми комерціалізації науково-технічних розробок : тези доповідей IV Міжнар. наук.-практ. відео конфр. (Львів, 23-24 трав. 2012 р.). Львів, 2012. С. 94-95.

2. Гаевская М.В. Экологическая ответственность бизнеса и экологические рейтинги. Экологическая эфрфективность производства. Минск, 2008. 15 с.

3. Екологічна відповідальність: досвід ЄС та можливості для України : Аналіт. доп. / Ресурсно-аналітичний центр «Суспільство і довкілля». 2018. URL: https://www.rac.org.ua/uploads/content/447/files/ webenvironmentalliabilityua2018.pdf

4. Колісник 3.Б. Вплив екологічної відповідальності на економічні результати діяльності лісопромислового сектора. Науковий вісник НЛтУ України. 2013. Вип. 23.10. С. 72-79. URL: http://nbuv.gov.ua/UJRN/ nvnltu_2013_23

5. Кукутич Є.Ю. Екологічне підприємництво у забезпеченні сталого економічного зростання : автореф. дис. ... канд. економ. наук : 08.00.06. Рада по вивченню продуктивних сил України НАНУ. Київ, 2007. 20 с.

6. Купалова Г.І. Екологічне підприємництво як невід'ємна складова сталого розвитку України. Вісник Київського національного університету імені Тараса Шевченка. 2011. Вип. 26. С. 35-39.

7. Магомедова Т.Л. Формирование стратегии управления промышленным предприятием на основе принципов экологической ответственности бизнеса : авторефр. дис. ... канд. економ. наук. ФГБОУ ВПО «Самарский государственный технический университет». Самара, 2012. 20 с.

8. Мазуркевич П. Корпоративна екологічна відповідальність: чи можлива спільна система КСВ? 2016. Siteresources.worldbank.org

9. Мельник Л.Г. Екологічна економіка : підручник / 3-е вид. випр. і допов. Суми, 2006. 367 с.

10. Милль Д.Ст. Основы политической экономии и некоторые аспекты ее применения в социальной философии. URL: https://economics.studio/ekonomicheskih-ucheniy-istoriya/mill-djsosnovyi-politicheskoyekonomii-88631.html

11.Петрушенко М.М., Бондар Т.В., Гриценко Т.Г. Принципи моделювання організаційно-економічного механізму екологізації промислового підприємства. Вісник СумДУ. Серія 72 «Економіка». 2011. № 1. С. $72-82$.

12. Про охорону навколишнього природного середовища. Закон України від 12. квітня 2018 р. / Верховна Рада України. URL: http://zakon2.rada.gov.ua/laws/show/1264-12

13. Погорелов Ю.С., Вахлакова В.В. Показники екологізації діяльності промислового підприємства. Економіка. Менеджмент. Підприємництво. 2013. С. 48-56.

14.Огородник В.В. Вплив екологічного компонента соціальної відповідальності на економіку країни. Глобальні та національні проблеми економіки. 2015. Вип. 7. С. 612-615 URL: http://globalnational.in.ua/ archive/7-2015/132.pdf

15. Охріменко О.О. Соціальна відповідальність : навч. посіб. для вищ. навч. закл. / О.О. Охріменко, Т.В. Іванова. Національний технічний університет України «Київський політехнічний інститут». 2015. С. 102-111.

16. Садченко Е.В. Формирование системы экономического стимулирования природопользования в условиях экологизации предпринимательской деятельности. Устойчивое развитие : сб. науч. тр. / Е.В. Садченко, С.О. Никола. Болгария, София, 2014. Вып. № 20. С. 62-70.

17. Салдаева М.Н. Экологическая ответственность бизнеса в России: позитивный опыт и препятствия для дальнейшего развития. Вестник Самарского государственного технического университета. Серия : Экономические науки. 2013. № 3. С. 148-154.

18. Хаянок Т.М. Ефрективність використання соціальної та екологічної відповідальності в управлінні агропідприємством. Вісник Дніпропетровського державного аграрного університету. 2015. № 1. С. 15-21, 192.

19. Шаповал В.М., Коваленко О.А. Функції та елементи соціальної відповідальності сучасних компаній. 3б. матеріалів I міжнар. наук.-практ. інтернет-конср. «Детермінанти сталого розвитку організацій в умовах глобалізації», (Дніпропетровськ 15-16 груд. 2014 р.) / відп. ред. В.М. Шаповал; М-во освіти і науки України, Нац. гірн.ун-т. Дніпро : НГУ, 2015. С. 158-160, 184 с.

20. Швиданенко Г.О. Розвиток підприємства на еколого-економічних засадах : монографрія / Швиданенко Г.О., Криворучкіна О.В., Матукова Д.Г. КНЕУ, 2017. 184 с. ISBN 978-966-926-140-3

21.Aerts, W., Cormier, D. Media legitimacy and corporate environmental communication. Accounting, organizations and society. 2009. № 34(1). P. 1-27.

22. Carroll A. B. The pyramid of corporate social responsibility: toward the moral management of organizational stakeholders. Business Horizons. 1991. Vol. 34(4), pp. 39-48.

23. Comission of the European Communities. Green Paper: Promoting a European framework for corporate social responsibility. Luxembourg, 2001. Available at: www.europa.eu/rapid/press-release_DOC-01-9_en.pdf 
24. Kasych A., Vochozka M. Conceptual provisions of development of Ukrainian national innovation system. Науковий вісник Полісся. 2017. № 2(10). Ч. 2. С. 16-23.

25. Kasych A., Vochozka M. Medothological support of the enterprise sustainable development management. Маркетине і менеджмент інновацій. 2018. № 1. С. 371-381.

26. Marshall A. S., Brown D. The strategy of sustainability. A system perspective on environmental initiative. California Management Review. 2003. Vol. 46. № 1. P. 101-126.

27. Shapira Ph., GökA. Probing green industry enterprises in the UK: A new identification approach. Technological forecasting and social change. 2014. Vol. 85. P. 93-10.

28. Shapoval V., Ashcheulova A. Ecologic Component of Social Responsibility of Business (Experience of Poland and Ukraine). Об'єднана Європа: перспективи розвитку : монографія / науки. ред. О.І. Амоша. Дніпропетровськ : Національний гірничий університет; Вроцлав, 2010. 254 с.

\section{REFERENCES:}

1. Borovyk O.N. (2012) Ekolohichne pidpryiemnytstvo ta yoho perevahy [Ecological entrepreneurship and its advantages]. Upravlinnia innovatsiinym protsesom v Ukraini: problemy komertsializatsii naukovo-tekhnichnykh rozrobok (Management of innovation: process in Ukraineproblems of commercialization of scientific and technical developments): tezy dopovidei IV Mizhnar. nauk.-prakt. video konf. (Lviv, 23-24 trav. 2012 r.). Lviv, pp. 94-95. (in Ukrainian)

2. Gaevskaya M.V. (2008) Ekologicheskaya otvetstvennost' biznesa i ekologicheskie reytingi [Environmental responsibility of business and environmental ratings]. Ekologicheskaya effektivnost' proizvodstva (Environmental efficiency of production. Minsk, 15 p. (in Russian)

3. Ekolohichna vidpovidalnist: dosvid YeS ta mozhlyvosti dlia Ukrainy (2018) [Environmental responsibility: EU experience and opportunities for Ukraine]: Analytl dop. / Resource and analytical Center "Society and Environment". Retrieved from: https://www.rac.org.ua/uploads/content/447/files/webenvironmentalliabilityua2018.pdf (in Ukrainian)

4. Kolisnyk Z.B. (2013) Vplyv ekologhichnoji vidpovidaljnosti na ekonomichni rezuljtaty dijaljnosti lisopromyslovogho sektora [Influence of ecological responsibility on economic results of activity of forest industry sector]. Scientific Bulletin National Forestry University of Ukraine (Scientific herald of NLTU of Ukraine), vol. 23, no. 10, pp. 72-79. Retrieved from: http://nbuv.gov.ua/UJRN/nvnltu_2013_23 (in Ukrainian)

5. Kukutych Ye.Yu. (2007) Ekolohichne pidpryiemnytstvo u zabezpechenni staloho ekonomichnoho zrostannia [Ecological entrepreneurship in ensuring sustainable economic growth]: author's ref. dis. .. cand. economy. sciences: 08.00.06. Council for the Study of Productive Forces of Ukraine of NASU. Kyiv, 20 p. (in Ukrainian)

6. Kupalova Gh.I. (2011) Ekologhichne pidpryjemnyctvo jak nevidjemna skladova stalogho rozvytku Ukrajiny [Ecological entrepreneurship as an integral component of sustainable development of Ukraine]. Bulletin of Taras Shevchenko National University of Kyiv, vol. 26, pp. 35-39. (in Ukrainian)

7. Maghomedova T.L. (2012) Formyrovanye strateghyy upravlenyja prombshlennыm predpryjatyem na osnove pryncypov ekologhycheskoj otvetstvennosty byznesa [Formation of an industrial enterprise management strategy based on the principles of environmental responsibility of business]: author's ref. dis. ... cand. economy. sciences. FSBEI HPE "Samara State Technical University". Samara, 20 p. (in Russian)

8. Mazurkevych P. (2016) Korporatyvna ekologhichna vidpovidaljnistj: chy mozhlyva spiljna systema KSV? [Corporate environmental responsibility: is a joint CSR system possible?].

9. Melnyk L.H. (2006) Ekolohichna ekonomika [Ecological economics]: textbook / 3rd ed. correction of idopov. Sumy, 367 p. (in Ukrainian)

10. Mill' D.St. Osnovy politicheskoy ekonomii i nekotorye aspekty ee primeneniya $v$ sotsial'noy filosofii [Fundamentals of political economy and some aspects of its application in social philosophy]. Retrieved from: https://economics.studio/ekonomicheskih-ucheniy-istoriya/mill-djsosnovyi-politicheskoy-ekonomii-88631.html (in Russian)

11.Petrushenko M.M., Bondar T.V., Hrytsenko T.H. (2011) Pryntsypy modeliuvannia orhanizatsiinoekonomichnoho mekhanizmu ekolohizatsii promyslovoho pidpryiemstva [Principles of modeling of organizationaleconomic mechanism of greening of industrial enterprise]. Visnyk SumDU. Seriia 72 «Ekonomika», no. 1, pp. $72-82$. (in Ukrainian)

12. On Environmental Protection. Law of Ukraine 12.04.2018 / Verkhovna Rada of Ukraine. Retrieved from: http://zakon2.rada.gov.ua/laws/show/1264-12 (in Ukrainian)

13. Pohorelov Yu.S., Vakhlakova V.V. (2013) Pokaznyky ekolohizatsii diialnosti promyslovoho pidpryiemstva [Indicators of greening the activities of industrial enterprises]. Ekonomika. Menedzhment. Pidpryiemnytstvo, no. 25(2), pp. 48-56. (in Ukrainian) 
14. Oghorodnyk V.V. (2015) Vplyv ekologhichnogho komponenta socialjnoji vidpovidaljnosti na ekonomiku krajiny [The impact of the environmental component of social responsibility on the economy]. Globaljni ta nacionaljni problemy ekonomiky, vol. 7, pp. 612-615. Retrieved from: http://globalnational.in.ua/archive/7-2015/132.pdf (in Ukrainian)

15. Okhrimenko O.O. (2015) Socialjna vidpovidaljnistj [Social responsibility]: navch. posib. dlja vyshh. navch. zakl. I O.O. Okhrimenko, T.V. Ivanova. National Technical University of Ukraine «Kyiv Polytechnic Institute», pp. 102-111. (in Ukrainian)

16. Sadchenko E.V. (2014) Formirovanie sistemy ekonomicheskogo stimulirovaniya prirodopol'zovaniya $v$ usloviyakh ekologizatsii predprinimatel'skoy deyatel'nosti [Formation of a system of economic incentives for environmental management in the conditions of greening entrepreneurial activity]. Ustoychivoe razvitie (Sustainable development): sb. nauch. tr. / E.V. Sadchenko, S. O. Nikola. Bolgariya, Sofiya, no. 20, pp. 62-70. (in Russian)

17. Saldaeva M.N. (2013) Ekologicheskaya otvetstvennost' biznesa v Rossii: pozitivnyy opyt i prepyatstviya dlya dal'neyshego razvitiya [Environmental responsibility of business in Russia: positive experience and obstacles for further development]. Vestnik Samarskogo gosudarstvennogo tekhnicheskogo universiteta. Seriya: Ekonomicheskie nauki, no. 3, pp. 148-154. (in Russian)

18. Khajanok T.M. (2015) Efektyvnistj vykorystannja socialjnoji ta ekologhichnoji vidpovidaljnosti v upravlinni aghropidpryjemstvom [The effectiveness of the use of social and environmental responsibility in the management of agricultural enterprises]. Visnyk Dnipropetrovskoho derzhavnoho ahrarnoho universytetu, no. 1, pp. 15-21, 192. (in Ukrainian)

19. Shapoval V.M., Kovalenko O.A. (2015) Funktsii ta elementy sotsialnoi vidpovidalnosti suchasnykh kompanii [Functions and elements of social responsibility of modern companies)]. Zb. materialiv I mizhnar. nauk.-prakt. internetkonf. «Determinanty staloho rozvytku orhanizatsii v umovakh hlobalizatsii», (Dnipropetrovsk 15-16 hrud.2014 r.) / vidp. red. V.M. Shapoval; M-vo osvity i nauky Ukrainy, Nats. hirn.un-t. Dnipro: NHU, 184 p. (pp. 158-160). (in Ukrainian)

20. Shvydanenko H.O. (2017) Rozvytok pidpryiemstva na ekoloho-ekonomichnykh zasadakh [Development of the enterprise on ecological and economic bases]: monohrafiia (a monograph) / Shvydanenko H.O., Kryvoruchkina O.V., Matukova D.H. KNEU, 184 p. ISBN 978-966-926-140-3 (in Ukrainian)

21. Aerts W., Cormier D. (2009) Media legitimacy and corporate environmental communication. Accounting, organizations and society, no. 34(1), pp. 1-27.

22. Carroll A. B. (1991) The pyramid of corporate social responsibility: toward the moral management of organizational stakeholders. Business Horizons, vol. 34(4), pp. 39-48.

23. Comission of the European Communities (2001) Green Paper: Promoting a European framework for corporate social responsibility. Luxembourg. Available at: europa. eu/rapid/press-release_DOC-01-9_en.pdf

24. Kasych A., Vochozka M. (2017) Conceptual provisions of development of Ukrainian national innovation system. Naukovyi visnyk Polissia, no. 2(10), ch. 2, pp. 16-23. (in Ukrainian)

25. Kasych A., Vochozka M. (2018) Medothological support of the enterprise sustainable development management. Marketynh i menedzhment innovatsii, no. 1, pp. 371-381. (in Ukrainian)

26. Marshall A.S., Brown D. (2003) The strategy of sustainability. A system perspective on environmental initiative. California Management Review, vol. 46, no. 1, pp. 101-126.

27. Shapira Ph., Gök A. (2014) Probing green industry enterprises in the UK: A new identification approach. Technological forecasting and social change, vol. 85, pp. 93-10.

28. Shapoval V., Ashcheulova A. (2010) Ecologic Component of Social Responsibility of Business [Experience of Poland and Ukraine]. United Europe: prospects of development: monograph / science. ed. O.I. Amosha. Dnipropetrovsk: National Mining University. Wroclaw, $254 \mathrm{p}$. 